\title{
Measuring Teacher Creativity-Nurturing Behavior and Readiness for 21st Century Classroom Management
}

\author{
Jaggil Apak, Universiti Malaysia Sabah, Malaysia \\ Muhamad Suhaimi Taat, Universiti Malaysia Sabah, Malaysia \\ Norazah Mohd Suki, Universiti Utara Malaysia, Malaysia
}

iD https://orcid.org/0000-0002-8422-2449

\begin{abstract}
The COVID-19 pandemic is drastically reshaping the 21 st century classroom management to remote learning via various online teaching and learning platforms across the world. The aims of this study are threefold: to assess the level of creativity nurturing behavior and teacher readiness for 21 st century classroom management, to test the differences of this relationships towards teaching experience, and to examine the relationship between teachers' creativity nurturing behavior and their readiness for 21st century classroom management. The ANOVA test revealed that teachers' creativity-nurturing behavior is significantly different according to teaching experience. What's more, regression analysis revealed that teachers' creativity-nurturing behavior affects their readiness for 21 st century classroom management. Teachers should stimulate positive changes in pedagogical practice to transform the classroom into a more active learning community with greater potential for creativity. Direction for future research is also furnished.
\end{abstract}

\section{KEYWORDS}

21st Century Classroom Management, Creativity Nurturing Behavior, Education, Exploratory Factor Analysis, ICT, Malaysia, Teacher Readiness, Teaching Experience, Technology

\section{INTRODUCTION}

The full-blown coronavirus disease 2019 (COVID-19) has resulted in reshaping of the 21 st century classroom management to remote learning via the utilization of various online teaching and learning platforms like Google Classroom, Google Meet, Microsoft Team, etc. across the world. 
Sharing of knowledge, and learning materials among virtual learning communities are borderless at anytime, anywhere globally (Ismail, 2020). This necessitates teacher readiness to nurture creative students' behavior in 21 st century classroom management. The vision is to transform this space into an environment conducive for creative learning (Ministry of Education Malaysia, 2013). This development highlights the critical role of teachers' 21 st century classroom management as they are the most effective agents for change in the classroom (Izani Ibrahim \& Yahya Don, 2014; Sellars, 2012). Effective classroom management is critical to ensure that students achieve the six 21 st century aspirations, which are the acquisition of knowledge, thinking skills, leadership skills, bilingual skills, ethics, spirituality, and national identity (Ministry of Education Malaysia, 2013). The education system needs to facilitate the transition process of producing a future workforce that is equipped with knowledge and skills to face the challenges of the 21 st century (Karpudewan \& Chong Keat, 2017). Teacher readiness to assume this responsibility is therefore paramount.

Readiness for change is important to determine the success of new implementations in the organization (Anghelachea \& Bentea, 2012; Davis, 1989; Rafferty, Jimmieson \& Armenakis, 2013; Teo, 2010). The changes in the national education system, specifically the enculturation of the 21st century classroom and its management require teacher readiness (MoE, 2013). Effective teachers interact with their students, thereby creating an environment that respects, encourages, and stimulates learning. These effective teacher expectations can only be materialized through effective classroom management (Ayebo \& Assuah, 2017). Consequently, the situation in the classroom has become more complex (Ahmad \& Ghavifekr, 2014). Past studies acknowledged that teacher influence was very significant in determining the outcomes of change (Erwin \& Garman, 2010; Hall \& Hord, 2011). The critical role of teachers in the classroom is also due to their close relationships with their students (Tai, Omar, Mohamad Sahari \& Khuan, 2015). However, teacher readiness is often found problematic and commitment is frequently low when faced with change (Toprak \& Summak, 2014). Thus, education reforms are not possible without the prior endorsement of teaching staff.

Teacher creativity has long been acknowledged as an important element in producing creative and innovative learners (Olawale, Adeniyi \& Olubela, 2010; Craft, 2015; Saibon, Har, \& Abd Razak, 2017; Doyle, 2019). In the classroom, the nurturing of creativity and innovation among teachers is a similar component (Karwowski, Lebuda, Wisniewska \& Gralewski, 2013; Baruah \& Paulus, 2019). Promoting creativity in the classroom is an important aspect of the teacher-student relationship (Cropley, 1997; Sawyer, 2012), encompassing factors such as varying expectations, mutual respect, creative behavior, flexibility and discussions (Davies, Jindal-Snape \& Collier, 2013; Ucus \& Acar, 2018). Teachers' mindset of the traditional teaching and learning process using chalk and talk, one-way input delivery should be gradually transformed into accepting and incorporating creative pedagogy in teaching (Saibon et al, 2017).

Enhancing and nurturing creative and critical thinking skills are important goals for 21 st century learning (Bloom \& Doss, 2019). Creativity has the potential to stimulate positive change in pedagogical practices and turn the classroom into an active and vibrant learning community (Erin Justyna, 2016). Unfortunately, the literature reveals that the creative potential of students is not nurtured in the classroom (Beghetto, 2010; Sawyer, 2010; Bloom \& Doss, 2019; Fasko \& Rizza, 2019; Ahmadi, Peter, Lubart, \& Besancon, 2019). In the Malaysian context, the current form of assessment which emphasizes on examinations does little to encourage our young minds to explore further because the teaching and learning are skewed towards memorization of facts (Karpudewan \& Chong Keat, 2017). This should not be the case, as creativity has a fundamental role in the learning process and specifically greater retention of knowledge (Elaldi \& Batdi, 2016; Gajda, Karwowski \& Beghetto, 2017).

Creativity is perceived as the capacity to produce ideas and products that are both novel and useful or appropriate (Runco \& Jaeger, 2012). In this study, creative nurturing referring to teachers themselves being creative teachers and nurturing adults to students. In order to ensure students' competency in the 21 st century job market, the creativity nurturing behavior of the teacher in the classroom plays a critical role (Kampylis, 2010; Chan \& Yuen, 2014). The 21st century reinforces the fact that higher- 
order thinking skills must be taught to the current students (Osborne, 2013). Accordingly, the aims of this study are threefold: (i) to assess the level of creativity nurturing behavior and teacher readiness for 21 st century classroom management, (ii) to test differences in teachers' creativity nurturing behavior and teachers' readiness for 21 st century classroom management with teaching experience, and (iii) to examine the relationship between teachers' creativity nurturing behavior and their readiness in 21 st century classroom management.

\section{LITERATURE REVIEW}

Readiness for change is defined as an individual's beliefs, attitude and purpose regarding the extent to which the change is necessary and the organisation's capability to realise this change (Armenakis, Harris, \& Mossholder, 1993). Scholars like Armenakis and Bedeian (1999), Holt, Armenakis, Field and Harris (2007), and Neves (2009) opine that the concept of change encompasses one's beliefs in the appropriateness, support and value of the change. Vakola (2013) states that effective organizational change cannot be realized without the readiness of the staff to change themselves, and subsequently support the suggested initiative. Based on these concepts, teacher readiness in this study is defined as the teachers' beliefs, attitudes, and purpose to change and support the implementation of the 21st century classroom.

Past scholars like Summak, Baglibel and Samancioglu (2010) found the level of teacher readiness for technology acceptance to be moderate, while Apak and Taat (2018) concluded that teachers' readiness was being practiced at a high level. Conversely, the readiness level was ascertained as low by Noh, Mustafa and Ahmad (2014). Furthermore, Ertmer, Ottenbreit-Leftwich, Sadik, Sendurur and Sendurur (2012) determined that teachers' beliefs were related to the technology integration practices in their teaching. Ismail, Bokhare, Azizan and Azman (2013) highlighted the high level of teachers' technology acceptance although their readiness in relation to the use of the cellular telephone in teaching was at a very low level. Their study also failed to establish a link between teaching experience and teachers' perceptions on the role of the cellular phone.

The 4P framework offers a definition of creativity and comprises four interconnected strands: a Person goes through a Process in order to produce a novel Product in the context of the environment or Press (Doyle, 2019). Cropley (1997) synthesises the creativity nurturing behavior of teachers into nine main strategies: (1) encouraging students to learn independently and on their own, (2) applying cooperative and social integration teaching styles, (3) motivating students towards mastery of basic knowledge to nurture diversity in thinking styles, (4) delaying assessment of students' ideas until they have arrived at full conclusions, (5) encouraging flexibility or fluidity of thinking, (6) emphasizing self-assessment, (7) giving due consideration to students' suggestions and questions, (8) facilitating opportunities for learning through the provision of various materials and resources, and (9) helping students manage disappointment or failure to ensure that the spirit to embark on new or extraordinary pursuits remains. Based on this synthesis, Soh (2015) points to creativity nurturing behavior as the appropriate teacher response; when effected at the proper time, it will inevitably encourage students to work harder in future.

Soh (2015) further details the nine aspects of creativity nurturing behavior of teachers as freedom, integration, motivation, consideration, flexibility, assessment, questioning, opportunities, and disappointment. In this study, the creativity nurturing is defined as teaching practice aimed at fostering students' creativity through specific behavior and strategies, based on their classroom expertise while at the same time being open to creative ideas and demonstrating control, flexibility in thought and action, and appreciating freedom of thinking.

In regards to examination of creativity nurturing behavior of teachers in the classroom, Turner (2013) concluded that teachers' experience had no influence on their creativity nurturing behavior. Research by Stone (2015) concurs with this finding. However, Loogma, Kruusvall and Umarik (2012) found that teachers with less than five years teaching experience demonstrated higher levels 
of creativity and innovation in implementing e-learning compared to those with greater experience. According to Cheung (2012), although most teachers held similar beliefs on what constituted good creativity practices, the link between this belief and teacher classroom practice was not seen to be consistent.

In another study, Snell (2013) found the experience levels of teachers did not produce differences in their perceptions. Besides, Al-Nouh, Abdul-Kareem and Taqi (2014) reported that the attitudes of English Language teachers towards creative thinking and what occurred in the classroom were positive. Less experienced teachers were also found to have a more positive attitude towards creative thinking compared to other groups. Accordingly, Dikici (2014) concurred that experience was important in influencing the link between thinking style and creativity nurturing. Through multi-group structural equation modelling, Huang, Lee and Dong (2019) discovered that teacher-perceived practicality and teachers' creative behavior were significantly related to teachers' intention to engage in creative teaching for all the participants.

Based on the aforementioned literature, the following hypotheses were postulated:

H1: Teachers' creativity nurturing behavior significantly differs based on their teaching experience.

$\mathrm{H} 2$ : Teachers' readiness for 21 st century classroom management significantly differs based on their teaching experience.

H3: Teachers' creativity nurturing behavior significantly affects their readiness for 21 st century classroom management.

\section{METHODOLOGY}

A self-administered questionnaire was chosen for collecting data due to alternatives states are limited by using fixed response questions. A group of 500 secondary school teachers in Sabah, Malaysia was selected as respondents in this study because they were very keen to take full advantage of ICT facilities to strengthen teaching and learning skills. Of this, the present research has secured 439 completed questionnaires from convenience sampling technique, equating to $88 \%$ response rate. This sample size met the threshold set by Krejcie and Morgan (1970). They were derived from a total population of 14,698 teachers employed at government secondary schools in Sabah, Malaysia. Of this, a quarter of the respondents $(25 \%)$ reported that they had less than ten years of teaching experience, followed by $38 \%$ with ten to twenty years, and 37\% with more than 20 years' experience. With regards to gender distribution, $60 \%$ of the respondents were females, and $40 \%$ were males. More than three-quarters of the respondents were Kadazan-Dusun ethnicity (78\%), followed by Malays (14\%), and Chinese (8\%).

The questionnaire was designed in three sections. Section A requires the respondents to furnish data regarding teaching experience, and Section B presents the instruments of creativity nurturing behavior and teacher readiness which were adapted from Creativity Fostering Teacher Behavior Index developed by Soh (2015), and were designed in a 5-point Likert scale from 1 - strongly disagree to 5 strongly agree. The final section, Section C includes the respondents' socio-demographic profiles. Data were analyzed using one-way Analysis of Variance (ANOVA) to test differences in teachers' creativity nurturing behavior and teachers' readiness for 21st century classroom management with teaching experience. Next, regression analysis was employed to examine the hypothesized relationships.

\section{FINDINGS}

Research findings from exploratory factor analysis, ANOVA, and regression analysis based on instruments of creativity nurturing behavior and teacher readiness are detailed next. 


\section{Exploratory Factor Analysis}

For the purposes of construct validity, a total of 40 items of Creativity Nurturing Behavioral are loaded for analysis involving nine constructs, namely Independence (4 items), Integration (5 items), Motivation (5 items), Judgement (5 items), Flexibility (4 items), Evaluation (5 items), Question (5 items), Opportunities (4 items), and Frustration (3 items). The Bartlett Test of Sphericity showed significant $\left(\mathrm{x}^{\wedge} 2=2765.27, \mathrm{df}=990, \mathrm{p}<0.05\right)$. Meanwhile, the Kaiser-Meyer-Olkin sampling sufficiency test value is 0.82 . This value is higher than 0.60 as suggested by Pallant (2013) and Coakes, Steed, and Ong (2009). The results of the exploratory factor analysis show that the loading factors of all items surpass 0.50 , signifying a reasonable and acceptable level, and align to the recommendation by Hair et al. (2010). The reliability test also shows a positive Cronbach's Alpha coefficient value of 0.929 for 40 items on Creativity Nurturing Behavior variables. Table 1 shows some sample item constructs and their respective loading factors.

Measuring teacher readiness involved adapting the instruments that include Technology Acceptance Measure (TAM) by Davis (1989), Technology Acceptance Measure for Preservice Teachers (TAMPST) by Teo (2010) and Readiness for Organizational Change Scale by Holt, Armenakis, Field, and Harris (2007). Several researchers such as Chang, Lieu, Liang, Liu, and Wong (2102), Pynoo, Tondeur, van Braak, Duyck, Sijnave, and Duyck (2012), and Svendsena, Johnsen, S-Sorensenc, and Vittersod (2013) had earlier used the TAM instrument by Davis (1989). The questionnaire developed by Teo (2010) was the result of adaptation from Davis (1989) and was built specifically to measure the attitude of technology acceptance among pre-service teachers. Measuring the teacher readiness to organizational change involved adapting the questionnaire developed by Holt et al. (2007). The instrument has proven to have high credibility and reliability to measure the readiness of individuals to change (Weiner, Amick, \& Lee, 2008; Haffar, Al-Karaghouli, \& Ghoneim, 2014). Some studies have used this questionnaire such as Tummers, Steijn, and Bekkers (2012), McKay, Kuntz, and Naswall (2013), and Bakari, Hunjra, and Niazi (2017).

This instrument consists of 28 items representing two sets of constructs of Teacher Readiness variables: Organizational Change ( 15 items) and Technology Acceptance (13 items) constructs. The sub-scale for Organizational Change consists of Appropriateness (5 items), Management Support (3 items), Change Efficacy (4 items), and Personally Beneficial ( 3 items). The measurement scale for each item used is 5 points Likert scale. Technology Acceptance has four sub-scales: Perceived Usefulness (4 items), Perceived Ease of Use (3 items), Facilitating Conditions (3 items), and Attitude Toward Technology ( 3 items). The Bartlett Test of Sphericity showed significant $\left(\mathrm{x}^{\wedge} 2=2030.39, \mathrm{df}=378\right.$, $\mathrm{p}<0.05$ ). Meanwhile, the Kaiser-Meyer-Olkin sampling sufficiency test value is 0.77 far higher than 0.60. The results of the analysis show that the loading factor for all items is beyond 0.50 , inferring a reasonable and acceptable level as recommended by Hair et al. (2010). Reliability test also showed a positive Alpha Cronbach coefficient value of 0.883 for 28 items on Teacher Readiness variables. Table 2 shows some sample item constructs and their respective loading factors.

\section{Level of Creativity Nurturing Behavior and Teacher Readiness for 21st Century Classroom Management}

Figure 1 shows that creativity nurturing behavior (85.0\%) and teacher readiness (78.6\%) are rated at a high level. Even though the latter percentage is slightly lower than the former, the data indicates that the majority of the teachers have a high readiness for 21 st century classroom management.

\section{Difference Between Teachers' Creativity Nurturing Behavior and Teaching Experience}

Difference between teachers' creativity nurturing behavior and teaching experience is reported in Table 3. The mean score for teachers with more than 20 years of teaching experience is higher $(M=4.057$, $\mathrm{SD}=0.369, \mathrm{~N}=162)$ than the mean score of teachers with less than ten years of experience $(\mathrm{M}=3.923$, $\mathrm{SD}=0.329, \mathrm{~N}=112)$ and between ten to twenty years of experience $(\mathrm{M}=4.006, \mathrm{SD}=0.374, \mathrm{~N}=165)$. 
Table 1. Exploratory factor analysis of creativity nurturing behavior

\begin{tabular}{|c|c|c|}
\hline Construct & Statements & $\begin{array}{c}\text { Factor } \\
\text { Loading }\end{array}$ \\
\hline \multirow[t]{3}{*}{ Independence } & $\begin{array}{l}\text { - "I teach my students the basics and leave them to find out more for } \\
\text { themselves." }\end{array}$ & 0.62 \\
\hline & • "I leave questions for my students to find out for themselves." & 0.86 \\
\hline & $\begin{array}{l}\text { • "I leave open-ended questions for my students to find the answers for } \\
\text { themselves." }\end{array}$ & 0.55 \\
\hline \multirow[t]{3}{*}{ Intergration } & • "In my class, students have opportunities to share ideas." & 0.53 \\
\hline & • "Students in my class have opportunities to do group work regularly." & 0.57 \\
\hline & $\begin{array}{l}\text { - "Students in my class are encouraged to contribute to the lesson with their } \\
\text { ideas and suggestions." }\end{array}$ & 0.51 \\
\hline \multirow[t]{3}{*}{ Motivation } & - "Learning the basic knowledge/skills well is emphasized in my class." & 0.81 \\
\hline & - "I emphasize the importance of mastering the essential knowledge." & 0.62 \\
\hline & $\begin{array}{l}\text { - "My students know that I expect them to learn the basic knowledge and } \\
\text { skills well." }\end{array}$ & 0.53 \\
\hline \multirow[t]{3}{*}{ Judgement } & $\begin{array}{l}\text { - "When my students have some ideas, I get them to explore further before I } \\
\text { take a stand." }\end{array}$ & 0.79 \\
\hline & $\begin{array}{l}\text { - "I do not give my view immediately on students' ideas, whether I agree or } \\
\text { disagree with them." }\end{array}$ & 0.82 \\
\hline & $\begin{array}{l}\text { - "I encourage students to do things differently although doing this takes up } \\
\text { more time." }\end{array}$ & 0.73 \\
\hline \multirow[t]{3}{*}{ Flexibility } & • "In my class, I probe students' ideas to encourage thinking." & 0.54 \\
\hline & • "I like my students to take time to think in different ways." & 0.76 \\
\hline & • "I allow students to deviate from what they are told to do." & 0.81 \\
\hline \multirow[t]{3}{*}{ Evaluation } & $\begin{array}{l}\text { - "I expect my students to check their own work instead of waiting for me to } \\
\text { correct them." }\end{array}$ & 0.63 \\
\hline & • "My students know that I expect them to check their own work before I do." & 0.59 \\
\hline & • "I allow my students to show one another their work before submission." & 0.65 \\
\hline \multirow[t]{3}{*}{ Question } & • "My students know I do not dismiss their suggestions lightly." & 0.73 \\
\hline & • "When my students have questions to ask, I listen to them carefully." & 0.65 \\
\hline & • "I listen to my students' suggestions even if they are not practical." & 0.74 \\
\hline \multirow[t]{3}{*}{ Opportunities } & $\begin{array}{l}\text { - "I encourage my students to try out what they have learned from me in } \\
\text { different situations." }\end{array}$ & 0.54 \\
\hline & $\begin{array}{l}\text { - "I don't mind my students trying out their own ideas and deviating from } \\
\text { what I have shown them." }\end{array}$ & 0.68 \\
\hline & • "Students are allowed to go beyond what I teach them within my subject." & 0.55 \\
\hline \multirow[t]{3}{*}{ Frustration } & - "My students who are frustrated can come to me for emotional support." & 0.86 \\
\hline & $\begin{array}{l}\text { - "I help students who experienced failure to cope with it so that they regain } \\
\text { their confidence." }\end{array}$ & 0.51 \\
\hline & $\begin{array}{l}\text { - "I encourage students who have frustration to take it as part of the learning } \\
\text { process." }\end{array}$ & 0.51 \\
\hline
\end{tabular}


Table 2. Exploratory factor analysis of teacher readiness

\begin{tabular}{|c|c|c|}
\hline Construct & Statements & $\begin{array}{l}\text { Factor } \\
\text { Loading }\end{array}$ \\
\hline \multirow[t]{3}{*}{ Appropriateness } & • "I think that the organization will benefit from this change." & 0.81 \\
\hline & • "This change will improve our organization's overall efficiency." & 0.68 \\
\hline & $\begin{array}{l}\text { • "The time we are spending on this change should be spent on something } \\
\text { else." }\end{array}$ & 0.67 \\
\hline \multirow{3}{*}{$\begin{array}{l}\text { Management } \\
\text { Support }\end{array}$} & - "Our senior leaders have encouraged all of us to embrace this change." & 0.78 \\
\hline & - "Our senior leaders have encouraged all of us to embrace this change." & 0.82 \\
\hline & - "Every senior manager has stressed the importance of this change." & 0.88 \\
\hline \multirow[t]{3}{*}{ Change Efficacy } & $\begin{array}{l}\text { - "I do not anticipate any problems adjusting to the work I will have when } \\
\text { this change is adopted." }\end{array}$ & 0.67 \\
\hline & $\begin{array}{l}\text { - "There are some tasks that will be required when we change that I don't } \\
\text { think I can do well." }\end{array}$ & 0.67 \\
\hline & $\begin{array}{l}\text { - "My past experiences make me confident that I will be able to perform } \\
\text { successfully after this change is made." }\end{array}$ & 0.83 \\
\hline \multirow[t]{3}{*}{ Personally Beneficial } & $\begin{array}{l}\text { - "I am worried I will lose some of my status in the organization when this } \\
\text { change is implemented." }\end{array}$ & 0.81 \\
\hline & $\begin{array}{l}\text { - "This change will disrupt many of the personal relationships I have } \\
\text { developed." }\end{array}$ & 0.87 \\
\hline & • "My future in this job will be limited because of this change." & 0.87 \\
\hline \multirow{3}{*}{$\begin{array}{l}\text { Perceived } \\
\text { Usefulness }\end{array}$} & • "Using technology will improve my work." & 0.88 \\
\hline & • "Using technology will increase my productivity." & 0.90 \\
\hline & • "Using technology will enhance my effectiveness." & 0.89 \\
\hline \multirow{3}{*}{$\begin{array}{l}\text { Perceived Ease } \\
\quad \text { of Use }\end{array}$} & • "I find technology a useful tool in my work." & 0.76 \\
\hline & • "I find technology easy to use." & 0.51 \\
\hline & - "My interaction with technology would be clear and understandable." & 0.88 \\
\hline \multirow[t]{3}{*}{$\begin{array}{l}\text { Facilitating } \\
\text { Conditions }\end{array}$} & $\begin{array}{l}\text { - "When I need help to use technology, a specific person is available to } \\
\text { provide assistance." }\end{array}$ & 0.89 \\
\hline & - "When I need help to use technology, guidance is available to me." & 0.88 \\
\hline & $\begin{array}{l}\text { - "When i need help to use technology, specialized instruction is available to } \\
\text { help me." }\end{array}$ & 0.68 \\
\hline \multirow{3}{*}{$\begin{array}{l}\text { Attitude Toward } \\
\text { Technology Use }\end{array}$} & •"Working with technology is fun." & 0.53 \\
\hline & • "I like using technology." & 0.52 \\
\hline & $\begin{array}{l}\text { - "I look forward to those aspects of my job that require me to use } \\
\text { technology." }\end{array}$ & 0.66 \\
\hline
\end{tabular}

This difference indicates that the group with more than twenty years' experience practices creativity nurturing behavior more often in the classroom.

Subsequently, a one-way ANOVA was run to test the difference between teachers' creativity nurturing behavior and teaching experience. $\mathrm{H} 1$ postulates that teachers' creativity nurturing behavior significantly differs based on their teaching experience. As indicated in Table 4, ANOVA test was found to be statistically significant for the difference between teachers' creativity nurturing behavior and teaching experience at an alpha level of $0.05, \mathrm{~F}(2,436)=4.746$. Thus, $\mathrm{H} 1$ was supported as 
Figure 1. Level of creativity nurturing behavior and teacher readiness for 21 st century classroom management

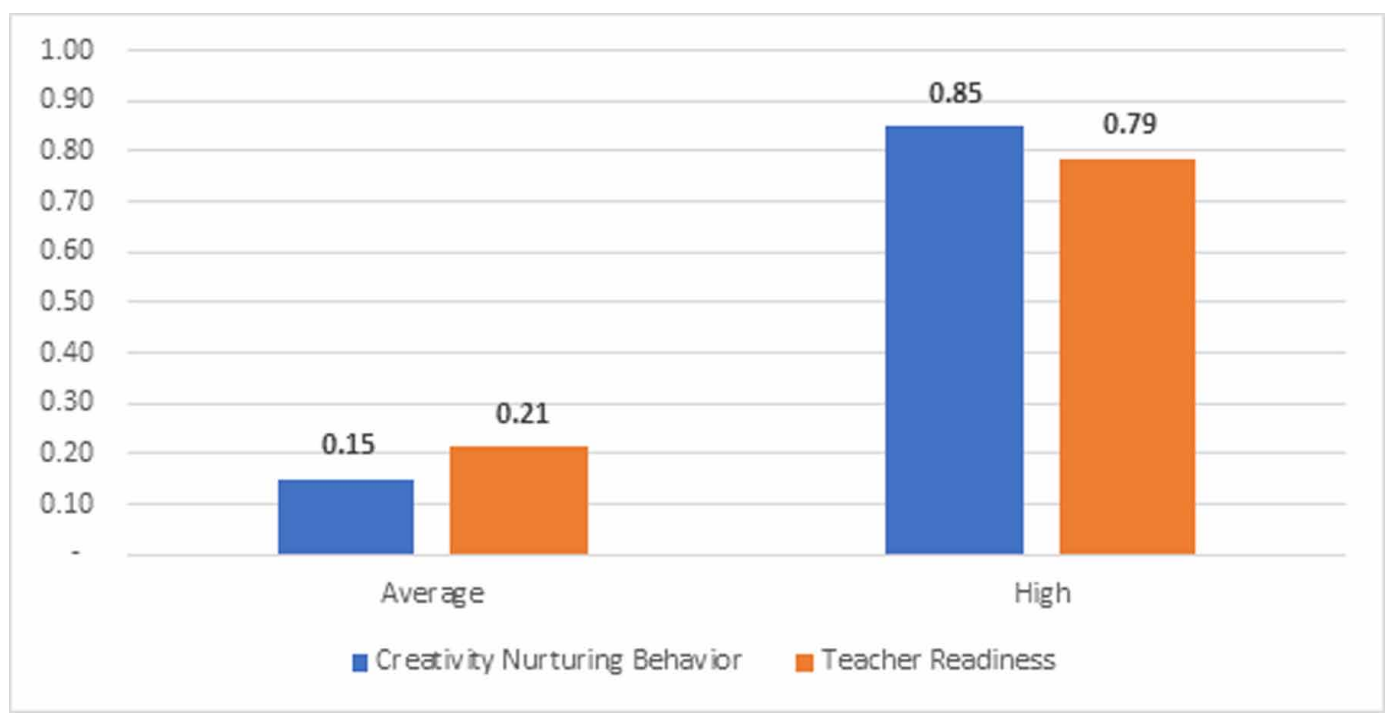

Table 3. Descriptive analysis of creativity nurturing behavior based on teaching experience

\begin{tabular}{|c|c|c|c|c|}
\hline \multicolumn{2}{|c|}{ Variable } & N & Mean & SD \\
\hline \multirow{3}{*}{$\begin{array}{c}\text { Creativity Nurturing } \\
\text { Behavior }\end{array}$} & Less than 10 years & 112 & 3.923 & 0.329 \\
\cline { 2 - 5 } & $10-20$ years & 165 & 4.006 & 0.374 \\
\cline { 2 - 5 } & More than 20 years & 162 & 4.057 & 0.348 \\
\cline { 2 - 5 } & Total & 439 & 4.004 & 0.357 \\
\hline
\end{tabular}

predicted. This demonstrates that the mean scores for creativity nurturing behavior based on teaching experience were significantly different.

Additionally, a Post Hoc Multiple Comparisons test was performed to examine pairs of mean scores in the same groups that show a significant difference. Table 5 reveals that a significant mean difference was found between teachers with less than ten years' experience and those with more than 20 years' $(\mathrm{p}=0.006)$. Specifically, the mean score for the teachers with less than ten years' experience $(M=3.923)$ was lower than that for those with more than 20 years' $(M=4.057)$. The difference in the mean value is 0.134 . These results imply that there is difference in creativity nurturing behavior based on teaching experience.

Table 4. ANOVA between creativity nurturing behavior and teaching experience

\begin{tabular}{|c|c|c|c|c|c|c|}
\hline Variable & & $\begin{array}{c}\text { Sum of } \\
\text { Squares }\end{array}$ & df & Mean Square & $F$ & Sig. \\
\hline \multirow{2}{*}{$\begin{array}{c}\text { Creativity } \\
\text { Nurturing } \\
\text { Behavior }\end{array}$} & Between Groups & 1.187 & 2 & .593 & 4.746 & 0.009 \\
\cline { 2 - 7 } & Within Groups & 54.512 & 436 & .125 & & \\
\cline { 2 - 7 } & Total & 55.698 & 438 & & & \\
\hline
\end{tabular}

*Significant difference at $p<0.05$ (2-tailed) 
Table 5. Post Hoc Tukey HSD analysis of creativity nurturing behavior based on teaching experience

\begin{tabular}{|c|c|c|c|c|}
\hline \multirow{2}{*}{ Variable } & $\begin{array}{c}\text { (I) Teaching } \\
\text { Experience }\end{array}$ & (J) Teaching Experience & $\begin{array}{c}\text { Difference } \\
\text { Mean } \\
(\mathbf{I}-\mathbf{J})\end{array}$ & Sig. \\
\hline \multirow{2}{*}{$\begin{array}{c}\text { Creativity } \\
\text { Nurturing } \\
\text { Behavior }\end{array}$} & Less than 10 years & $10-20$ years & -0.082 & 0.140 \\
\cline { 2 - 5 } & \multirow{2}{*}{$10-20$ years } & More than 20 years & $-0.134^{*}$ & $0.006^{*}$ \\
\cline { 2 - 5 } & & Less than 10 years & 0.082 & 0.140 \\
\cline { 2 - 5 } & More than 20 years & Oess than 10 years & -0.052 & 0.384 \\
\cline { 2 - 5 } & & $10-20$ years & $0.134^{*}$ & $0.006^{*}$ \\
\hline
\end{tabular}

${ }^{*}$ Significant difference at $p<0.05$ (2-tailed)

Table 6. Descriptive analysis of teacher readiness for 21 st century classroom management based on teaching experience

\begin{tabular}{|l|c|c|c|c|}
\hline \multicolumn{2}{|c|}{ Variable } & N & Mean & SD \\
\hline \multirow{3}{*}{ Teacher Readiness } & Less than 10 years & 112 & 3.912 & 0.289 \\
\cline { 2 - 6 } & $10-20$ years & 165 & 3.921 & 0.338 \\
\cline { 2 - 6 } & More than 20 years & 162 & 3.944 & 0.365 \\
\cline { 2 - 6 } & Total & 439 & 3.927 & 0.337 \\
\hline
\end{tabular}

\section{Difference Between Teachers' Readiness for 21st Century Classroom Management and Teaching Experience}

An examination of the difference between teachers' readiness for 21 st century classroom management and teaching experience was then performed. A descriptive analysis of Table 6 indicates that teachers' readiness for 21 st century classroom management differs based on their teaching experience. The mean score for teachers with more than 20 years' experience $(\mathrm{M}=3.944, \mathrm{SD}=0.3944, \mathrm{~N}=162)$ was higher than teachers with less than ten years' experience $(\mathrm{M}=3.912, \mathrm{SD}=0.289, \mathrm{~N}=112)$ and teachers with between ten to twenty years' $(M=3.921, S D=0.338, N=165)$. Findings infer that teachers with more than 20 years' experience have a higher readiness for 21 st century classroom management compared to the other two groups. Meanwhile, teachers with less than ten years' experience are less ready to manage 21 st century classrooms.

The differences of mean scores noted above precipitated a one-way ANOVA test. H2 posits that teachers' readiness for 21 st century classroom management significantly differs based on teaching experience. Table 7 demonstrates that there is an insignificant difference between teacher readiness

Table 7. ANOVA comparing teacher readiness for $21 \mathrm{st}$ century classroom management and teaching experience

\begin{tabular}{|c|c|c|c|c|c|c|}
\hline Variable & & Sum of Squares & df & Mean Square & $F$ & Sig. \\
\hline \multirow{2}{*}{ Teacher Readiness } & Between groups & .077 & 2 & 0.039 & 0.340 & 0.712 \\
\cline { 2 - 7 } & Within groups & 49.556 & 436 & 0.114 & & \\
\cline { 2 - 7 } & Total & 49.633 & 438 & & & \\
\hline
\end{tabular}

${ }^{*}$ Significant difference at $p<0.05$ (2-tailed) 
and experience, whereby $F(2,436)=0.340$ at $p>0.05$. Hence, $\mathrm{H} 2$ is rejected. This implies that the mean scores for teachers' readiness based on teaching experience show no significant difference.

\section{Impact of Creativity Nurturing Behavior on Teachers' Readiness for 21st Century Classroom Management}

Regression analysis was performed to assess H3, which postulates that teachers' creativity nurturing behavior significantly affects their readiness for 21 st century classroom management. The regression model $\mathrm{R}^{2}$ of 0.184 , reveals that 18.4 percent of the variance in teachers' readiness can be explained by their creativity nurturing behavior. A close examination of Table 8 shows that teachers' creativity nurturing behavior $(\beta=0.429)$ is positively related to their readiness as $p<0.01$. Thus, H3 is supported. Results signify that teachers' creativity nurturing behavior significantly affects their readiness for 21 st century classroom management.

Table 8. Regression analysis on the influence of creativity nurturing behavior on teacher readiness

\begin{tabular}{|c|c|c|c|c|}
\hline \multicolumn{2}{|c|}{ Predictor Variable } & $\boldsymbol{\beta}$ & $t$-value & $p$-value \\
\hline \multicolumn{2}{|c|}{ Creativity Nurturing Behavior } & .429 & 9.914 & 0.000 \\
\hline $\mathrm{R}^{2}$ & $=.184$ & & & \\
\hline$\Delta \mathrm{R}^{2}$ & $=.182$ & & & \\
\hline $\mathrm{F}$ & $=98.289$ & & & \\
\hline
\end{tabular}

${ }^{*}$ Significant difference at $p<0.05$ (2-tailed)

\section{DISCUSSION}

This research assessed the level of creativity nurturing behavior and teacher readiness for 21 st century classroom management, tested differences in teachers' creativity nurturing behavior and their readiness in relation to their teaching experience. Additionally, an examination of these relationships was also performed. The descriptive analysis showed that creativity nurturing behavior among teachers is at a high level. This is in line with the Ministry of Education's (2013) desire for a greater emphasis on creativity as indicated in the Malaysia Education Blueprint 2013-2025. This study reinforces the findings of previous studies such as those by Cheung (2012), Hondzel (2013), Ozkal (2014), and Chan and Yuen (2015) wherein teachers testify to their utmost beliefs in creativity practice in the classroom. However, this study contradicts the finding of Erin Justyna (2016), which suggests that classroom practices lack creativity consistency.

A closer assessment of whether teachers' creativity nurturing behavior differs based on teaching experience is put forward in H1. A one-way ANOVA test revealed that this hypothesis is supported. Teachers who had more than 20 years' teaching experience obtained higher mean scores. The experienced teachers have higher creativity and innovation than less-experienced teachers. This finding was in line with research of Rubenstein, Ridgley, Callan, Karami and Ehlinger (2018) and Snell (2013). Conversely, the findings of Zbainos and Anastasopoulou (2012) suggested that less experienced teachers had higher creativity, a contention supported by Al-Nouh et al. (2014).

Additionally, $\mathrm{H} 2$ postulates that teachers' readiness for 21 st century classroom management differs significantly based on teaching experience. This hypothesis produced insignificant results and in line with the discoveries by Toprak and Summak (2014) and Hung (2016). The teaching experience group did not show significant difference in terms of teacher readiness. However, it was found to be incongruent with previous studies, such as those conducted by Inan and Lowther (2010), 
Msila (2015) and Hung (2016). However, the present study supports the discoveries of Nasri, Vahid Dastjerdy, Eslami Rasekh and Amirian (2017), which postulate that there is no significant difference in terms of teacher readiness between the less-experienced and experienced groups.

Furthermore, the subsequent hypothesis $\mathrm{H} 3$ was supported as creativity nurturing behavior was seen to significantly affect teacher readiness for 21 st century classroom management. This finding reinforced those of Chan and Yuen (2014) and Huang, Lee, and Dong (2019), who demonstrated that trust and teachers' creative personality influenced creativity cultivation in the classroom. These encounters are consistent with Serdar's (2015) findings. The present findings infer that teachers encourage students to nurture creativity and uphold creative thinking in 21 st century classroom management by actively contribute to the lesson with interesting ideas and suggestions, and take time to think in different ways to deviate from what they are told to do. Additionally, teachers encourage students to try out what they have learnt in different situations, and emphasize the importance of mastering the essential knowledge.

\section{CONCLUSION}

This research endows vital theoretical and practical implications. In respect of theoretical implications, this study adds further support to various theory and creativity models, such as Torrance's (1997) Creativity Development Model and Rhode's (1961) 4P Creativity Model. Although only a few concepts are addressed, the level of teachers' behavior in cultivating high creativity could explain the application of both theory and model in this study. Besides, practical implications are addressed in an ongoing effort to uphold effective 21st century classroom management, teachers should have high levels of readiness in order to be able to cope with transformation, whether in terms of organizational change or the integration of new technology.

What's more, teachers' competency should be in line with current aspirations for change, specifically in relation to interactive and virtual teaching applications. High levels of readiness could allow teachers to be more creative and innovative in their management. As teachers play an important role as models and mentors in cultivating students' creativity in the classroom, stimulating positive changes in pedagogical practice should transform the classroom into a more active learning community with greater potential for creativity.

Future research should expand the sampling coverage to take into account teachers from private schools, high performance schools, sports schools, technical and vocational schools, science schools, and mission and religious schools besides teachers from a regular and fully funded government secondary school. As creativity nurturing behavior variable has insignificant effect on teacher readiness, future studies should consider several other variables that could possibly make a greater contribution towards variance changes in terms of teacher readiness, such as leadership, school climate, and organizational culture. 


\section{REFERENCES}

Ahmad, R., \& Ghavifekr, S. (2014). School Leadership for the $21^{\text {st }}$ Century: A Conceptual Overview. Malaysian Online Journal of Educational Management, 2(1), 48-61.

Al-Nouh, N. A., Abdul-Kareem, M. M., \& Taqi, H. A. (2014). Primary School EFL Teachers' Attitudes Towards Creativity and Their Perceptions of Practice. English Language Teaching, 7(9), 74-90. doi:10.5539/elt.v7n9p74

Anghelachea, V., \& Bentea, C. C. (2012). Educational Changes and Teachers' Attitudes Towards Change. Social and Behavioral Sciences, 33, 593-597. doi:10.1016/j.sbspro.2012.01.190

Apak, J., \& Taat, M. S. (2018). The Influence of Teachers' Readiness Towards $21^{\text {st }}$ Century Classroom Management. Malaysian Journal of Social Sciences and Humanities, 3(4), 6-22.

Armenakis, A. A., \& Bedeian, A. G. (1999). Organizational Change: A Review of Theory and Research in the 1990s. Journal of Management, 25(3), 293-315. doi:10.1177/014920639902500303

Armenakis, A. A., Harris, S. G., \& Mossholder, K. W. (1993). Creating Readiness for Organizational Change. Human Relations, 46(6), 681-703. doi:10.1177/001872679304600601

Ayebo, A., \& Assuah, C. (2017). Exploring Teachers' Knowledge of Classroom Management and Control. Malaysian Journal of Learning and Instruction, 14(1), 169-185. doi:10.32890/mjli2017.14.1.7

Bakari, H., Hunjra, A. I., \& Niazi, G. S. K. (2017). How Does Authentic Leadership Influence Planned Organizational Change? The Role of Employees' Perceptions: Integration of Theory of Planned Behavior and Lewin's Three Step Model. Journal of Change Management, 17(2), 155-187. doi:10.1080/14697017.2017.1 299370

Baruah, J., \& Paulus, P. B. (2019). Collaborative Creativity and Innovation in Education. In Creativity Under Duress in Education? (pp. 155-177). Springer. doi:10.1007/978-3-319-90272-2_9

Beghetto, R. A. (2010). Creativity in The Classroom. In J. C. Kaufman \& R. J. Sternberg (Eds.), The Cambridge Handbook of Creativity (pp. 447-466). Cambridge University Press. doi:10.1017/CBO9780511763205.027

Bloom, L. A., \& Doss, K. (2019). Using Technology to Foster Creative and Critical Thinking in the Classroom. In Handbook of Research on Promoting Higher-Order Skills and Global Competencies in Life and Work (pp. 70-84). IGI Global. doi:10.4018/978-1-5225-6331-0.ch005

Bramwell, G., Reilly, R. C., Lilly, F. R., Kronish, N., \& Chennabathni, R. (2011). Creative Teachers. Roeper Review, 33(4), 228-238. doi:10.1080/02783193.2011.603111

Chan, S., \& Yuen, M. (2014). Personal and Environmental Factors Affecting Teachers' Creativity Fostering Practices in Hong Kong. Thinking Skills and Creativity, 12, 69-77. doi:10.1016/j.tsc.2014.02.003

Chan, S., \& Yuen, M. (2015). Teachers' Beliefs and Practices for Nurturing Creativity in Students: Perspectives from Teachers of Gifted Students in Hong Kong. Gifted Education International, 31(3), 200-213. doi:10.1177/0261429413511884

Chang, J. L., Lieu, P. T., Liang, J. H., Liu, H. T., \& Wong, S. L. (n.d.). A Causal Model of Teacher Acceptance of Technology. Educational Research Review, 7(5), 102-110.

Cheung, R. H. P. (2012). Teaching for Creativity: Examining the Beliefs of Early Childhood Teachers and Their Influence on Teaching Practices. Australasian Journal of Early Childhood, 37(3), 43-51. doi:10.1177/183693911203700307

Coakes, S. J., Steed, L., \& Ong, C. (2009). SPSS Version 16.0 for Windows: Analysis Without Anguish. John Wiley \& Sons Australia.

Craft, A. (2015). Creativity, Education and Society: Writings of Anna Craft. Institute of Education Press.

Cropley, A. J. (1997). Fostering creativity in the classroom: General principles. In M. A. Runco (Ed.), The Creativity Research Handbook (Vol. 1, pp. 83-114). Hampton Press. 
Davies, D., Jindal-Snape, D., Collier, C., Digby, R., Hay, P., \& Howe, A. (2013). Creative Learning Environments in Education - A Systematic Literature Review. Thinking Skills and Creativity, 8, 80-91. doi:10.1016/j. tsc. 2012.07.004

Davis, F. D. (1989). Perceived Usefulness, Perceived Ease of Use, and User Acceptance of Information Technology. Management Information Systems Quarterly, 13(3), 319-339. doi:10.2307/249008

Dikici, A. (2014). Relationships between Thinking Styles and Behaviors Fostering Creativity: An Exploratory Study for the Mediating Role of Certain Demographic Traits. Educational Sciences: Theory and Practice, 14(1), 179-201.

Dikici, A., \& Soh, K. (2015). Indexing Creativity Fostering Teacher Behavior: Replication and Modification. Higher Education of Social Science, 9(3), 1-10.

Doyle, C. L. (2019). Speaking of Creativity: Frameworks, Models, and Meanings. In Creativity Under Duress in Education? (pp. 41-62). Springer. doi:10.1007/978-3-319-90272-2_3

Elaldi, S., \& Batdi, V. (2016). Comparing Effects of Different Applications on Preservice Teachers: A MetaAnalysis. Journal of Education and Training Studies, 4(7), 70-81. doi:10.11114/jets.v4i7.1456

Erin Justyna, M. A. (2016). Creativity in Higher Education Curriculum: A Qualitative Case Study of Pedagogical Processes and Practices (Doctoral Thesis). Texas Tech University.

Ertmer, P. A., Ottenbreit-Leftwich, A. T., Sadik, O., Sendurur, E., \& Sendurur, P. (2012). Teacher Beliefs and Technology Integration Practices: A Critical Relationship. Computers \& Education, 59(2), 423-435. doi:10.1016/j.compedu.2012.02.001

Erwin, D. G., \& Garman, A. N. (2010). Resistance to Organizational Change: Linking Research and Practice. Leadership and Organization Development Journal, 31(1), 39-56. doi:10.1108/01437731011010371

Fasko, D., \& Rizza, M. G. (2019). Role of Creativity in Educational Systems and the Change Process. In Creativity Under Duress in Education? (pp. 383-398). Springer. doi:10.1007/978-3-319-90272-2_20

Gajda, A., Beghetto, R. A., \& Karwowski, M. (2017). Exploring Creative Learning in The Classroom: A MultiMethod Approach. Thinking Skills and Creativity, 24, 250-267. doi:10.1016/j.tsc.2017.04.002

Haffar, M., Al-Karaghouli, W., \& Ghoneim, A. (2014). An Empirical Investigation of The Influence of Organizational Culture on Individual Readiness for Change in Syrian Manufacturing Organizations. Journal of Organizational Change Management, 27(1), 5-22. doi:10.1108/JOCM-04-2012-0046

Hall, G. E., \& Hord, S. (2011). Implementing Change: Patterns, Principles, and Potholes (3rd ed.). Pearson.

Holt, D. T., Armenakis, A. A., Field, H. S., \& Harris, S. G. (2007). Readiness for Organizational Change: The Systematic Development of a Scale. The Journal of Applied Behavioral Science, 43(2), $232-255$. doi:10.1177/0021886306295295

Hondzel, C. M. D. (2013). Fostering Creativity: Ontario Teachers' Perceptions, Strategies, and Experiences (Doctoral Dissertation). Ontario, Canada: The University of Western Ontario.

Huang, X., Lee, J. C. K., \& Dong, X. (2019). Mapping the factors influencing creative teaching in mainland China: An exploratory study. Thinking Skills and Creativity, 31, 79-90. doi:10.1016/j.tsc.2018.11.002

Hung, M. L. (2016). Teacher Readiness for Online Learning: Scale Development and Teacher Perceptions. Computers \& Education, 94, 120-133. doi:10.1016/j.compedu.2015.11.012

Ibrahim, I., \& Don, Y. (2014). Servant Leadership and Effective Changes Management in Schools. International Journal of Scientific and Research Publications, 4(1), 1-9.

Inan, F. A., \& Lowther, D. L. (2010). Factors Affecting Technology Integration in K-12 Classrooms: A Path Model. Educational Technology Research and Development, 58(2), 137-154. doi:10.1007/s11423-009-9132-y

Ismail, H. A. (2020). Users' Intention to Share Knowledge Using Wiki in Virtual Learning Community. International Journal of Information and Communication Technology Education, 16(1), 1-15. doi:10.4018/ IJICTE.2020010101 
Ismail, I., Bokhare, S. F., Azizan, S. N., \& Azman, N. (2013). Teaching Via Mobile Phone: A Case Study on Malaysian Teachers' Technology Acceptance and Readiness. Journal of Educators Online, 10(1), 1-38. doi:10.9743/JEO.2013.1.3

Kampylis, P. G. (2010). Fostering Creative Thinking: The Role of Primary Teachers. University of Jyväskylä.

Karpudewan, M., \& Chong Keat, M. (2017). The Effects of Classroom Learning Environment and Laboratory Learning Environment on The Attitude Towards Learning Science in the 21st-Century Science Lessons. Malaysian Journal of Learning and Instruction, Special Issue on Graduate Students Research on Education, 25-45.

Karwowski, M., Lebuda, I., Wisniewska, E., \& Gralewski, J. (2013). Big Five Personality Factors as The Predictors of Creative Self-Efficacy and Creative Personal Identity: Does Gender Matter? The Journal of Creative Behavior, 47(3), 215-232. doi:10.1002/jocb.32

Krejcie, R. V., \& Morgan, D. W. (1970). Determining Sampel Size for Research Activities. Educational and Psychological Measurement, 30(3), 607-610. doi:10.1177/001316447003000308

Levin, R. I., \& Rubin, D. S. (1998). Statistics for Management (7th ed.). Prentice-Hall, Upper Saddle River.

Loogma, K., Kruusvall, J., \& Umarik, M. (2012). E-learning as innovation: Exploring innovativeness of the VET teachers' community in Estonia. Computers \& Education, 58(2), 808-817. doi:10.1016/j.compedu.2011.10.005

Mariani \& Ismail. (2014). Sifat Personaliti Guru Untuk Pengajaran Kreatif. Proceedings of International Education Postgraduate Seminar 2014, 593-603.

McKay, K., Kuntz, J. R., \& Naswall, K. (2013). The Effect of Affective Commitment, Communication and Participation on Resistance to Change: The Role of Change Readiness. New Zealand Journal of Psychology, 42(2), 29-40.

Ministry of Education Malaysia. (2013). Malaysia Education Blueprint 2013-2025. PreSchool to Post-Secondary Education.

Msila, V. (2015). Teacher Readiness and Information and Communications Technology (ICT) Use in Classrooms: A South African Case Study. Creative Education, 6(18), 1973-1981. doi:10.4236/ce.2015.618202

Nasri, N., Vahid Dastjerdy, H., Eslami Rasekh, A., \& Amirian, Z. (2017). Iranian EFL Teachers' Practices and Learner Autonomy: Do Gender, Educational Degree, and Experience Matter? Innovation in Language Learning and Teaching, 11(2), 146-158. doi:10.1080/17501229.2015.1078337

Neves, P. (2009). Readiness for Change: Contributions for Employee's Level of Individual Change and Turnover Intentions. Journal of Change Management, 9(2), 215-231. doi:10.1080/14697010902879178

Noh, N. M., Mustafa, H. M. A., \& Ahmad, C. N. C. (2014). Predictive Relationship Between Technology Acceptance Readiness and the Intention to Use Malaysian Edu WebTV Among Library and Media Teachers. Procedia: Social and Behavioral Sciences, 116, 144-148. doi:10.1016/j.sbspro.2014.01.182

Olawale, S. G., Adeniyi, E. O., \& Olubela, O. I. (2010). Creativity Fostering Behavior as an Index of Productivity and Capacity Building Among Lecturers in Selected Universities in Ogun and Oyo States. Educational Research Review, 5(5), 257-262.

Osborne, J. (2013). The 21st Century Challenge for Science Education: Assessing Scientific Reasoning. Thinking Skills and Creativity, 10, 265-279. doi:10.1016/j.tsc.2013.07.006

Ozkal, N. (2014). Relationships Between Teachers' Creativity Fostering Behaviors and Their Self-Efficacy Beliefs. Educational Research Review, 9(18), 724-733. doi:10.5897/ERR2014.1816

Pallant, J. (2013). SPSS Survival Manual: A Step by Step Guide to Data Analysis Using IBM SPSS (5th ed.). Mc Graw-Hill.

Pynoo, B., Tondeur, J., van Braak, J., Duyck, W., Sijnave, B., \& Duyck, P. (2012). Teachers' Acceptance and Use of an Educational Portal. Computers \& Education, 58(4), 1308-1317. doi:10.1016/j.compedu.2011.12.026

Rafferty, A. E., Jimmieson, N. L., \& Armenakis, A. A. (2013). Change Readiness: A Multilevel Review. Journal of Management, 39(1), 110-135. doi:10.1177/0149206312457417

Rhodes, M. (1961). An analysis of creativity. Phi Beta Kappen Journal, 42, 305-310. 
Rubenstein, L. D., Ridgley, L. M., Callan, G. L., Karami, S., \& Ehlinger, J. (2018). How Teachers Perceive Factors That Influence Creativity Development: Applying A Social Cognitive Theory Perspective. Teaching and Teacher Education, 70, 100-110. doi:10.1016/j.tate.2017.11.012

Runco, M. A., \& Jaeger, G. J. (2012). The standard definition of creativity. Creativity Research Journal, 24(1), 92-96. doi:10.1080/10400419.2012.650092

Saibon, J., Har, A. L. C., \& Abd Razak, M. Z. (2017). Enhancing Knowledge of Bullying Behavior Through Creative Pedagogy Among Students. Malaysian Journal of Learning \& Instruction, 197-219.

Sawyer, R. K. (2010). Learning for creativity. In R. A. Beghetto \& J. C. Kaufman (Eds.), Nurturing Creativity in The Classroom (pp. 172-190). Cambridge University Press. doi:10.1017/CBO9780511781629.009

Sawyer, R. K. (2012). Explaining Creativity: The Science of Human Innovation. Oxford University Press.

Sellars, M. (2012). Teachers and Change: The Role of Reflective Practice. Procedia: Social and Behavioral Sciences, 55, 461-469. doi:10.1016/j.sbspro.2012.09.525

Serdar, R. A. (2015). Searching for Innovation, Creativity and $21^{\text {st }}$ Century Skills: A Case Study of a Suburban Elementary School District (Doctoral Dissertation). Chicago, IL: National-Louis University.

Snell, A. H. (2013). Creativity in Instrumental Music Education: A Survey of Winds and Percussion Music Teachers In New York State (Doctoral Dissertation). ProQuest Dissertations and Theses database. UMI No: 1318666608.

Soh, K. C. (2000). Indexing Creativity Fostering Teacher Behavior: A Preliminary Validation Study. The Journal of Creative Behavior, 34(2), 118-134. doi:10.1002/j.2162-6057.2000.tb01205.x

Soh, K. C. (2015). Creativity Fostering Teacher Behavior Around the World: Annotations of Studies Using the CFT Index. Cogent Education, 2(1), 1-18. doi:10.1080/2331186X.2015.1034494

Stone, D. L. (2015). Art Teachers' Beliefs About Creativity. Visual Arts Research, 41(2), 82-100. doi:10.5406/ visuartsrese.41.2.0082

Subramaniam, I. (2013). Teachers Perception on Their Readiness in Integrating Soft Skills in The Teaching and Learning. OSR Journal of Research \& Method in Education, 2(5), 19-29. doi:10.9790/7388-0251929

Summak, M. S., Baglıbel, M., \& Samancioglu, M. (2010). Technology Readiness of Primary School Teachers: A Case Study in Turkey. Procedia: Social and Behavioral Sciences, 2(2), 2671-2675. doi:10.1016/j. sbspro.2010.03.393

Svendsena, G. B., \& Johnsen, J. K. (2013). Personality and Technology Acceptance: The Influence of Personality Factors on The Core Constructs of The Technology Acceptance Model. Behaviour \& Information Technology, 32(4), 323-334. doi:10.1080/0144929X.2011.553740

Tai, M. K., Omar, A. K., Mohamad Sahari, N., \& Khuan, W. B. (2015). Teacher Change Beliefs: Validating a Scale with Structural Equation Modelling. School Leadership \& Management, 35(3), 266-299. doi:10.1080/1 3632434.2014.962503

Teo, T. (2010). The development, validation, and analysis of measurement invariance of the technology acceptance measure for pre-service teachers (TAMPST). Educational and Psychological Measurement, 70(6), 990-1006. doi: $10.1177 / 0013164410378087$

Toprak, M., \& Summak, M. S. (2014). Involvement in Change and Commitment to Change: A Study at Public Schools. International Journal of Social Sciences \& Education, 4(4), 953-968.

Torrance, E. P. (1997). Torrance Test of Creative Thinking. Personal Press, Ginn and Company.

Tummers, L., Steijn, B., \& Bekkers, V. (2012). Explaining the Willingness of Public Professionals to Implement Public Policies: Content, Context, and Personality Characteristics. Public Administration, 90(3), 716-736. doi:10.1111/j.1467-9299.2011.02016.x

Turner, S. (2013). Teachers' and Pupils' Perceptions of Creativity Across Different Key Stages. Research in Education, 89(1), 23-40. doi:10.7227/RIE.89.1.3 
Ucus, S., \& Acar, I. H. (2018). The Association Between Teachers' Innovativeness and Teaching Approach: The Mediating Role of Creative Classroom Behaviors. Social Behavior and Personality, 46(10), 1-16. doi:10.2224/ sbp. 7100

Vakola, M. (2013). Multilevel Readiness to Organizational Change: A Conceptual Approach. Journal of Change Management, 13(1), 96-109. doi:10.1080/14697017.2013.768436

Weiner, B. J., Amick, H., \& Lee, S. Y. (2008). Conceptualization and Measurement of Organizational Readiness for Change: A Review of The Literature in Health Services Research and Other Fields. Medical Care Research and Review: MCRR, 65(4), 379-436. doi:10.1177/1077558708317802 PMID:18511812

Zbainos, D., \& Anastasopoulou, A. (2012). Creativity in Greek Music Curricula and Pedagogy: An Investigation of Greek Music Teachers' Perceptions. Creative Education, 3(1), 55-60. doi:10.4236/ce.2012.31009

Jaggil Apak is an experienced teacher who has been teaching for 24 years. He has completed his Doctorate in Education Management at Universiti Malaysia Sabah in 2019. He is the recipient of the Dean's Award and Postgraduate Aspiration Award from Universiti Malaysia Sabah.

Muhamad Suhaimi Taat is an Associate Professor at the Faculty of Psychology and Education, University Malaysia Sabah. His research interest is in the field of pedagogy, educational sociology, teacher education, administration and etc. He has published more than one hundred articles in journals, book chapters, conference papers and newspapers. He collaborates with other disciplines in doing research such as environmental science, economic, etc. He also leads several research projects inside and outside the country. Apart from that he is always invited to give his speech and as keynote speaker at national and international events.

Norazah Mohd Suki is a Professor of Marketing and E-Commerce at Othman Yeop Abdullah Graduate School of Business (OYAGSB), Universiti Utara Malaysia (UUM). She is the recipient of Malaysia's Research Star Award 2018. Highly Commended Paper in the 2015 and the 2017 Emerald Literati Network Awards for Excellence, Winners of the IGI Global Seventh Annual Awards Excellence in Research Journal, etc. Her research interests include marketing research, consumer behaviour, M-commerce, E-commerce, E-marketing, green marketing, Islamic marketing, and areas related to marketing. She has mentored several post-graduate students, published more than 300 papers in referred journals, book chapters, books, and conference papers detailing her research activities, on top of coordinating and participating in several research projects. She is also the editor of several SCOPUS indexed books. She has wide-ranging experiences as an invited speaker on courses related to Structural Equation Modelling (SEM), Statistical Package for Social Sciences (SPSS) and research methodology. 